\title{
Kantowska filozofia dziejów i leżące u jej podstaw trudności
}

Temat niniejszego artykułu dotyczy problemów Kantowskiej filozofii dziejów. Problemy te aż po dziś dzień przyprawiają interpretatorów o ból głowy. Nie ulega wątpliwości, że Kantowska filozofia dziejów prima facie tylko z trudnością daje się powiązać z całokształtem stanowiska filozofa. Gdy rozważymy tę trudność bliżej, wydaje się, że istotne okazują się tu cztery problemy (1-4) dotyczące największych spośród trudności, jakie powinniśmy w tym wypadku wyjaśnić.

1. Problem dogmatyzmu. Na początek wyjątkowo trudne okazuje się pytanie, jakiego rodzaju teoretyczny status zgodnie ze stanowiskiem swego idealizmu transcendentalnego mógłby Kant przypisać jakimkolwiek rozważaniom historiozoficznym. Czy filozofia dziejów nie oznacza powrotu do metafizyki? W jaki sposób można by było pozwolić sobie na rozstrzygnięcie środkami krytycznej filozofii zagadnienia: czy w ogóle natura zmierza wraz z człowiekiem ku realizacji jego celów, a jeśli tak, to jakie one są? Eckart Förster $^{1}$ (2009: 194) formułuje na przykład następującą aporystyczną alternatywę: $\mathrm{z}$ jednej strony idea planu kryjącego się za historią nie może być pojęciem apriorycznym, bo wówczas należałoby chwytać konkretne fakty historyczne,

1 E. Förster, The Hidden Plan of Nature, [w:] J. Schmidt, A. Oksenberg Rorty (wyd.) Kant's 'Idea for a Univeral History with a Cosmopolitan Aim': A Critical Guide, Cambridge 2009, s. 187-199. 
ażeby je albo weryfikować, albo falsyfikować. $Z$ drugiej, pojęcie owo nie może też bazować na doświadczeniu, bo powinno tu chodzić o pewien ukryty plan, któremu nasze zwyczajne doświadczenie podlega. W piśmie Idea powszechnej historii w aspekcie kosmopolitycznym (dalej: Idee) czytamy (AA VIII 27):

Historię ludzkości jako całość uważać można za spełnianie ukrytego planu przyrody, by stworzyć wewnętrznie, zaś dla realizacji tego celu również zewnętrznie - doskonały ustrój jako jedyny stan, w którym może ona rozwinąć wszystkie dane ludzkości predyspozycje².

Żadne ludzkie doświadczenie nie byłoby wystarczające do tego, ażeby tak daleko idącą tezę albo uznać za słuszną, albo ją w zdecydowany sposób odrzucić. Pojęcie celu historii, podobnie jak pojęcie Boga, czy też ludzkiej wolności, kieruje się poza granice naszego poznania.

2. Problem heteronomii. Czy Kant poprzez swoją filozofię dziejów zamierza znaturalizować normy moralne i polityczne? Niektóre jego teksty mogłyby co najmniej coś takiego sugerować. Bo jeśli ludzkie uczynki są „tak samo jak wszystkie wydarzenia w przyrodzie, są określone przez powszechne prawa przyrody" (Idea, AA VIII 17) w takim razie wydaje się, że można je opisać równie naturalnie jak ,zmiany pogody, o których nie można wprawdzie niczego z góry przewidzieć szczegółowo”, „wzrost roślin, bieg rzek i inne wydarzenia przyrody" (tamże). Jeżeli w ten sposób rozumiemy nasze uczynki, to jak możemy równocześnie pojmować jako aktualne te $\mathrm{z}$ nich, które dotyczą normatywności? Normatywność jest fenomenem sui generis. W rozumieniu Kantowskim pozostaje ona co do swej ważności niezależna od faktów empirycznych gdy idzie o to, co aktualne, wiąże kategoryczność i atemporalność. Naturalizacja normatywności, gdyby to sformułować w teoretycznym języku Kanta, wykraczałaby poza heteronomię rozumu. Wydaje się więc, że Kantowski opis biegu dziejów w kwestii tego, co aktualne nie kładzie akcentu na autonomię rozumu oraz na problem osobistej odpowiedzialności, lecz raczej na automatyzm historyczny. Ostatecznie może tu chodzić o jakiś temporalny rozum, pojmowany jako duch świata. O ile autor wprowadza tu do rozważań jakiś „wykaz rozumu”, o tyle tenże jest deponentem autonomii rozumu ludz-

${ }^{2}$ I. Kant, Idea powszechnej historii w aspekcie kosmopolitycznym, przeł. M. Żelazny, [w:] I. Kant, Dzieła zebrane, t. 6, Toruń 2011, s. 40-41 (AA VIII 27). Skrót w nawiasie odnosi się do wydania dzieł Kanta Pruskiej Akademii Nauk: Akademie Ausgabe i oznacza kolejno numer tomu oraz strony (przyp. tłum.). 
kiego. Pauline Kleingeld ${ }^{3}$ bliżej określa trzy trudności, które wynikają z teorii dziejów dla Kantowskiej filozofii moralnej. Pierwsza dotyczy pytania, w jaki sposób prawo moralne może wciąż jeszcze być tu powszechnie ważne (universal validity problem). Druga brzmi: w jaki sposób prawo moralne może wciąż jeszcze coś wiązać w sposób ponadczasowy (das atemporality problem), trzecia zaś dotyczy sprzeczności, że liczne osoby musiałyby być bardziej wolne, aniżeli inne (moral equality problem).

3. Problem cynizmu. Problematyczna jest też myśl Kanta, że moralny lub polityczny postęp ludzkości wciąż cofa się pod wpływem naturalnych i socjalnych waśni, które w szczególności powodują „,ambicja, żądza władzy lub bogactwa" (Idee, AA VIII 21). Należałoby zapytać, czy tego typu nieporozumienia, gdy chodzi o te z nich, które zostały spowodowane przez człowieka, nie powinny przez to przynajmniej w części zostać każdorazowo usprawiedliwione, ba nazwane dobrymi. Refleksje tego typu snuje przede wszystkim Franco Zotta ${ }^{4}$.

4. Problem fatalizmu. Nie mniej poważnie brzmi podejrzenie, że inicjatywa podjęta przez motywowane moralnie osoby żyjące w czasach, gdy doszło do owych nieporozumień, a zmierzająca do tego, by przeciwko owym nieporozumieniom oponować i by je przezwyciężać, gdzie tylko jest możliwe, bywa osłabiana przez podkreślanie, że stanowi ona historyczną konieczność. Wojny, błędne kroki polityczne i socjalne katastrofy traktuje Kant tak, jak gdyby nie chodziło o wydarzenia o podłożu moralnym, lecz o zło polityczne, które należy znosić, gdyż odpowiada ono zamiarowi jakiejś mądrej opatrzności. $\mathrm{W}$ niniejszym artykule zarzuty te będę rozważał jako istotne, nie zajmując się nimi naturalnie po kolei. Myślę, że wszystkie te problemy sam Kant rozwiązał relatywnie zadowalająco.

\footnotetext{
${ }^{3}$ P. Kleingeld, Fortschritt und Vernunft. Zur Geschichtsproblem Kants, Würzburg 1999, s. 59.

${ }^{4}$ Przykładu na coś takiego dostarcza miejsce z Idei AA 21: „Człowiek chce zgody, lecz przyroda wie lepiej, co dla jego gatunku jest lepsze: ona chce niezgody”. Inny przykład znajdujemy w Idei (AA VIII 24 i nast.), gdzie Kant twierdzi, że wszelkie wojny dają się zrozumieć, jako zamiar natury, by przygotować najlepszy z możliwych międzynarodowy porządek - por. uwagi Zotty (2000: 192): „chodzi [Kantowi] raczej o to, ażeby móc pojąć nawet groteskowy rozum historii w sensie teodycei, czyli wciąż jeszcze jako reżim uświęcony. Ta argumentacja równa jest przeciwstawnej jej konkluzji naturalistycznej: historia zawsze jest już tym, czym być powinna."
} 
1. Wczesna Kantowska filozofia dziejów w pismach Odpowiedź na pytanie, co to jest Oświecenie ${ }^{5}$ i Idee.

Na pierwszy rzut oka wydaje się, że Kant nigdzie nie formułuje filozofii dziejów w sposób wyraźny. Żadne z jego pism ani wcześniejszych, a zatem Odpowiedź na pytanie, co to jest Oświecenie i Idea..., ani późniejszych, czyli Krytyka władzy sądzenia i Ku wieczystemu pokojowi, nie zawiera niczego, co by się zbliżało do teleologii dziejów takiej jak u Augustyna lub Joachima z Fiore, albo determinizmu historycznego w stylu Hegla albo Marksa. Kant nie podporządkowuje ludzkiej egzystencji ani pozbawionym sensu, lecz uporządkowanym stadiom, okresom i epokom, ani prawom biegu dziejów. Nie można również stwierdzić, ażeby historyczne fakty naciągał w taki sposób, by pasowały do zgrabnych schematów. Nie stylizuje się też na historycznego proroka albo prognostyka. Tym niemniej w jego filozofii pojawiają się cztery wymienione wcześniej trudności. Już wyobrażenie, że natura jest czymś w rodzaju samolubnego aktora, który w sposób niezauważalny miesza się od zaplecza w wolne ludzkie uczynki po to, by realizować jakiś plan lub osiągać jakiś ostateczny cel było Kantowi obce. W swym piśmie Idea powszechnej historii $w$ aspekcie kosmopolitycznym (1784) filozof nie pragnie bynajmniej zaprezentować żadnych ciągnących się rzekomo przez historię nici przewodnich. Ludzkie dzieje rozwijają się w jego mniemaniu w formę opartego na rozumie międzynarodowego porządku pokoju, który w przyszłości obejmie wszystkich ludzi.

Na początek jednak zwróćmy uwagę na inną z jego wczesnych rozpraw politycznych, małe pismo zatytułowane Odpowiedź na pytanie, czym jest Oświecenie? (1784). W piśmie tym Kant podejmuje dyskusję dotyczącą roli Kościoła w cywilnych związkach małżeńskich, który to temat, jako bardzo kontrowersyjny, pojawił się w tym samym roku w Berlinicher Monatsschrift. Kant pisze, że przy rozstrzyganiu wymienionego problemu musi dokonać rozróżnienia między powszechnym użyciem rozumu, które charakterystyczne jest dla uczonych i w efekcie musi być wolne, a użyciem prywatnym, które może być ograniczone przez szczególne obowiązki w stosunku do urzędu jak również te, które wynikają z lojalności. Ale rozwiązanie to nie jest dla niego ostateczne. Jeśli można byłoby uważać, że osoby sprawujące funkcje państwowe, takie jak oficerowie czy urzędnicy skarbowi, a w efekcie także

${ }^{5}$ Dalej I. Kant, Odpowiedź na pytanie, czym jest Oświecenie, przeł. T. Kupś, Dzieła zebrane, t. 6, wyd. cyt. (przyp. tłum.). 
przedstawiciele kleru powinni uznać, że idea prywatnego użycia rozumu jest dla nich zakazana, czyli, że nie mogą rozważać podlegających im spraw w sposób wolny i rozumny, to Kant formułuje tu coś, co stanowi przeciwieństwo owej zasady: także duchowni (teologowie) muszą, przynajmniej w określonym zakresie, trzymać się zasad rozumu. Wspólnota kościelna nie może być autoryzowana przez sam fakt, że wierni „zobowiązują się do [głoszenia] jakiegoś niezmiennego wyznania wiary" (AA VIII 38). Chodzi tu o to, żeby nie składać żadnego wyznania wiary, które wychodząc z teraźniejszości miałoby obowiązywać po wsze czasy.

Jest to bardzo ważne wymaganie Kanta, bo chrześcijańskie kościoły od późnego antyku (począwszy od IV i V wieku) charakteryzował taki sposób rozumienia wyznania wiary: jako deklaracji, której intencje ważne mają być zawsze. Kant formułuje tu odpowiedź ze swojego punktu widzenia: „Twierdzę, że jest to całkowicie niemożliwe” i „Byłoby to zbrodnią przeciw ludzkiej naturze” oraz w końcu „[oznaczałoby] naruszyć i podeptać święte prawa ludzkości" (AA VIII 39). Pozostaje dwuznaczne, co tu konkretnie filozof miał na myśli: $z$ jednej strony uznaje on za możliwe do przyjęcia, że pewna mała ludzi grupa wiążę się w jakimś okresie historycznym „kontraktem” sprowadzającym się do tego, ,ażeby na zawsze powstrzymać dalsze oświecenie ludzkiego rodzaju" (tamże). Zamiar Kanta rozumieć należy tu z perspektywy teleologii dziejów: ów kontrakt może być całkowicie do zaakceptowania dla ludzi żyjących w momencie jego zawarcia, ale ze względu na możliwą orientację rozumową przyszłych pokoleń oznacza przestępstwo, bo zakłada się w nim, że rozum osiągnął już pełne stadium swego rozwoju. Kant sądzi wręcz, że taki sposób ustanowienia go jest bezpodstawny również w odniesieniu do ludzi, którzy żyli w czasach jego powstania. Z drugiej strony filozof po raz pierwszy rozwija tu ideę suwerenności państwowej i to w osobliwy sposób sformułowanej:

Kamień probierczy tego wszystkiego, co odnośnie do jakiegoś ludu może być uchwalone jako prawo, jest zawarty w następującym pytaniu: czy dany lud mógłby sam nałożyć na siebie takie prawo? (AA VIII 39)

W takim sformułowaniu warte uwagi są dwa aspekty. Chodzi tu o zasadę podstawową (Prinzip), fundamentalną dla stworzonej przez Rousseau koncepcji suwerenności państwowej volante generale. Jednakże w odróżnieniu od Rousseau Kant chce w tym wypadku wykroczyć poza kryterium tekstu [ustawy] (probierza). Kto rzeczywiście doświadczył prawomocnej przemo- 
cy, a nie musi tu chodzić koniecznie o naród, musi zgodzić się z kryterium litery [prawa]. Kto rzeczywiście wciąż ćwiczy na sobie poczynania legalnej władzy, nie musi tu chodzić o naród, musi też zgadzać się z kryterium litery. Dla Kanta rozstrzygające jest, że zachodzi tu zgodność z wzorcem probierczym, jakim jest suwerenność państwowa. Idźmy dalej. Kryterium litery przypomina o formule autonomii imperatywu kategorycznego: tylko prawo ustanawiające samo siebie jest prawem uzasadnionym. Ale w odróżnieniu od imperatywu kategorycznego takie uzasadnienie nie będzie dokonane przez indywidualnych aktorów, nie zostanie też przez prawodawcę narzucone na nich, lecz raczej na kolektyw, czyli naród. Ale kwestia, kto dokładnie i według jakichś kryteriów coś testuje oraz co jest testowane, pozostaje niejasna. Kantowski naród z jednej strony jest czymś więcej aniżeli ludzkim indywiduum (które podlegać powinno moralnemu maksymalizmowi kategorycznego imperatywu), ale z drugiej czymś mniej, aniżeli ów uniwersalny podmiot, który ma na względzie uogólnienie uniwersalnych form prawa imperatywu kategorycznego.

Stwierdzimy więc jednoznacznie: tym, co stanowi merytoryczne centrum pisma Oświecenie, są idee jakiejś teleologii dziejów oraz określonej suwerenności narodów, rozumiane jako kryterium legalnego prawodawstwa. Co oznaczają te dwa detale? Chciałbym tu zwrócić uwagę na pewną trudność. Ani historia, ani naród nie są wielkościami, które łatwo dają się sprowadzić pod nadzór etyki imperatywu kategorycznego. Jeżeli ktoś rozważałby rozwój moralny w perspektywie przebiegu dziejów, wówczas interesowałoby go to, co dałoby się rozpoznać jako tendencja przerastająca wszystko, co indywidualne, a zarazem ponadczasowa. Trans-indywidualne i trans-czasowe perspektywy są jednakże równoważne dla filozofii moralności, której zadaniem jest orientowanie, zobowiązywanie i motywowanie indywiduum. Jeśli przyjmie się punkt widzenia narodu, to ma się do czynienia z perspektywą usytuowaną historycznie, ale nie uniwersalną, kolektywną, lecz nie nakazującą. Moralne pytania zawsze kierują się więc na to, co w człowieku jest istotą rozumną.

To, że Kantowskie podejście do filozofii politycznej określone jest przez rozważania z zakresu teologii dziejów, staje się widoczne natychmiast, gdy zwrócimy uwagę na opublikowaną w 1784 roku rozprawę Idea do historii powszechnej $w$ aspekcie kosmopolitycznym. Opiera się ona, jak wiadomo, na dziewięciu wynikających z siebie tezach. Jej punktem wyjścia staje się coś $\mathrm{w}$ rodzaju specyficznego essencjalizmu, połączonego z pewnym perfekcjonizmem, jakiego należałoby oczekiwać od tradycji arystotelesowskiej, a nie od Kanta. Pierwsza teza brzmi: „Wszelkim naturalnym predyspozycjom każde- 
go stworzenia jest pisane rozwinąć się kiedyś w pełni i zgodnie z celem" (AA VIII 18). Można byłoby zapytać, dlaczego wszystko powinno być właśnie takie, zwłaszcza w perspektywie pozaziemskiej, jak to wynika $\mathrm{z}$ twierdzenia drugiego. Współczesny czytelnik, znający teorię Darwina mógłby przypuszczać, że predyspozycje lwów do polowania oraz predyspozycje antylopy do ucieczki są raczej efektem wcześniejszego dopasowania się, aniżeli zwiastunem przyszłego rozwoju. Kant sądzi jednakże, że rozwój ludzkiego rozumu (który z tego powodu staje się naszą specyfiką) stymulowany jest przez naturę poprzez „antagonizm, czyli aspołeczną społeczność człowieka” (AA VIII 20): ludzie okazują zarówno tendencję do łączenia się we wspólnoty, jak i skłonność do izolacji. Centralna, gdy idzie o filozofię polityczną, okazuje się teraz teza 5 i 6 . Stworzenie: „podległego prawu społeczeństwa obywatelskiego” jak również „w pełni prawnego obywatelskiego ustroju” stanowi największe, najtrudniejsze oraz najważniejsze $\mathrm{w}$ historii zadanie, jakie natura przed nami postawiła (AA VIII 22). Kant powiada, że człowiek potrzebuje do tego „pana, który złamie w nim jego własną wolę i zmusi go, by był posłuszny woli powszechnej, przy której wolny może być każdy" (AA VIII 23). Chodzi tu o to, że człowiek z jednej strony musi podlegać władzy, która limituje jego antagonistyczne tendencje, a $\mathrm{z}$ drugiej strony tylko ona jest $\mathrm{w}$ stanie usankcjonować to, że będzie podlegał władzy, pod warunkiem, że nie narusza ona jego wolności. Jeżeli jednak mamy do czynienia $\mathrm{z}$ władzą, która umożliwia równocześnie wolność, wówczas powstaje problem, w jaki sposób można byłoby skłonić „Zwierzchnika powszechnej praworządności (sprawiedliwości)” do tego, ażeby zachowywał się w sposób sprawiedliwy, a nie egoistyczny (tamże).

W powyższym fragmencie interesujące jest to, że Kantowska wersja volente gènèrale ukazuje się tu normatywną podstawową zasadą polityczną, zrekonstruowaną $\mathrm{z}$ deskryptywnego punktu widzenia. Tak jest przynajmniej w rozprawce Czym jest oświecenie?, gdzie powszechna wola ukazuje się przynajmniej jako podstawowa normatywna zasada przyjętego w tekście kryterium. Warto jednak stwierdzić, że podstawowa zasada suwerenności narodu i powszechnej woli w drugim ze swych źródłowych kontekstów niewiele ma wspólnego z podstawową zasadą moralną.

W jaki sposób w Idei podstawa filozoficzna może stać się tak silnym założeniem, że poprzedzi ona teleologię dziejów (poprzez ukierunkowanie się na pełne rozwinięcie ludzkich predyspozycji w „stanie obywatelskim”)? Chcąc prawidłowo zrozumieć przesłanie Idei, nie można postrzegać teleologii dziejów jako czegoś stymulującego. Raczej należałoby tu odwrócić perspektywę, zwracając uwagę na faktyczne recypienty tej małej rozprawy Kanta. Jej 
odbiorca już z domu wyniósł przyzwyczajenie, ażeby traktować teleologię nie krytycznie (jak dziś czyni to większość z nas), lecz akceptująco. To, co Kant prezentuje w Idei ukaże się nam natychmiast w zupełnie innym świetle. Filozof koryguje tu poniekąd oczekiwania współczesnych mu odbiorców, oferując, zamiast teleologii dogmatycznej, teleologię krytyczną, a w miejsce teleologiczno-essencjalistycznej teorii rozwoju teorię krytyczno-oświecającą.

Współczesny Kantowi czytelnik Gothaischen Gelehrten Zeitung, który jako pierwszy wyrażałby opinię o jego przekonaniach na temat historii filozofii, podobnie jak czytelnik Berlinischen Monatsschrift, gdzie w 1784 roku ukazał się omawiany tu tekst, nie powinien więc podstawowej tezy Idei odebrać jako prowokacyjnej. Historia ludzkości ukazuje się tu jako uporządkowany, oparty na ugruntowujących go faktorach proces, którego punktu wyjścia należy poszukiwać w specyficznym essencjalizmie i którego punktem dojścia powinno być jakieś sekularyzowane oczekiwanie świętości (jak wskazuje na to pojęcie opatrzności). Gdy wystąpią oba te elementy, element essencjalizmu oraz element odniesienia do opatrzności, wówczas wykształcony czytelnik wyrastający z tradycji arystotelesowskiej, a z drugiej strony z tradycji teleologicznej, będzie mógł takiej koncepcji całkowicie zawierzyć. Obydwie te linie zbiegają się w punkcie, który Kant wyraża w następujący sposób: natura niczego nie robi nadaremnie (AA VIII 19). Czytelnik podejdzie wówczas do całego, interesującego nas zagadnienia nie $\mathrm{w}$ sposób tradycjonalistyczny, lecz raczej prowokacyjny, o ile czytając o postępie, oświeceniu, wolności, wykształceniu, rozwoju rozumowym, przyjmie równocześnie do wiadomości partie dotyczące społecznego antagonizmu oraz aspołecznej towarzyskości ludzi (AA VIII 20), czy też wreszcie dowie się o kształtowaniu: pełnej sprawiedliwości „społeczeństwa obywatelskiego”, a wreszcie usłyszy prognozę, że rzeczywiście dokonuje się postęp ku powszechnemu stanowi obywatelskiemu (AA VIII 28). Ażeby wczuć się w takie pomysły, współczesny Kantowi czytelnik musiał wczuć się w oświecenie. Właściwą innowacją Idei jest zatem synteza tradycji i oświecenia. Klasyczna teleologia dziejów zostaje w Ideach zreformowana w oświeceniowy sposób i zaprezentowana jest tu w wyraźnie osłabionej formie. Owo osłabienie dotyczy zwłaszcza punktu, w którym Kant obywa się bez determinizmu praw historii oraz bez dającego się prognozować biegu wydarzeń.

W istocie ważne jest, by podkreślić, że Kant, gdy idzie o jego model historii, nie potrzebuje żadnego determinizmu i rzeczywiście żadnego nie prezentuje. Nie jest na przykład konieczne stwierdzenie, że każde bez wyjątku wydarzenie w świecie jest częścią teleologicznej empirycznej historii, nakie- 
rowanej na zadany już cel (na przykład stan, że służący Kanta Lampe zaspał dokładnie tego poranka, gdy manuskrypt Idei powinien być wysłany do Berlina). Widzimy zatem, że ów cel był również uczestnikiem składających się na cały proces wydarzeń, a mianowicie okoliczności, które pośrednio okazały się mieć wpływ na pewien proces. Powoduje to poniekąd, że muszą istnieć również wydarzenia indyferentne.

Kant wydaje się jasno dostrzegać, że jego teza o możliwości systematycznego opisu rozwoju ludzkiej historii nie wymaga żadnego kauzalnego determinizmu. Dlaczego ma w tym względzie rację łatwo da się wyjaśnić, gdy dla porównania odwołamy się do darwinowskiej teorii ewolucji. Ta również w sposób indyferentny kieruje się przeciwko kauzalnemu determinizmowi. Można ją połączyć równie dobrze $\mathrm{z}$ teorią fizykalnego determinizmu, jak i indeterminizmu. I rzeczywiście darwinizm nie może być w typowy sposób broniony ani z pozycji standardowego determinizmu, ani zanegowany z pozycji indeterminizmu. Wszystko jedno, czy każdy występujący w świecie stan $\mathrm{W}_{2} \mathrm{z}$ punktu czasowego $\mathrm{t}_{2}$ da się $\mathrm{w}$ pełni wytłumaczyć na podstawie poprzedzającego go stanu $\mathrm{W}_{1} \mathrm{z}$ punktu $\mathrm{t}_{1}$ zgodnie $\mathrm{z}$ prawami natury, czy też nie. W przypadku obu tych uzasadniających teorii wydaje się, że można przyjąć, iż w ciągu milionów lat ewolucji dokonał się na Ziemi rozwój gatunków biologicznych, w trakcie którego silny wpływ selekcji doprowadził w znacznym stopniu do optymalnego dopasowania się tego, co specyficzne do odpowiednich warunków życia i środowiska. Kant w równie małym stopniu implikuje tu założenie determinizmu, jak i indeterminizmu. Moralny cel polityczny ludzkiej historii pozwala się określić bez potrzeby zakładania jakiegoś determinizmu. Teza o empirycznej historii rozwoju ludzkości bez problemu da się połączyć z tezą o faktycznym przebiegu historii politycznej. Ważne jest jedynie, że z faktów historycznych - jakie by one nie były - da się odczytać podstawową zasadę, która musi prowadzić ku społeczeństwu kosmopolitycznemu.

Okazuje się, że koncepcję historyczną Kanta z Idei łączy z ewolucyjną teorią Darwina pewien wspólny centralny punkt. Zgodnie $\mathrm{z}$ obydwiema koncepcjami wydarzenia tworzące proces rozwoju (a „rozwój” jest najczęściej używanym w Idei wyrażeniem teoretycznym) albo w sposób luźny, albo w ogóle w żaden nie odnoszą się do twierdzenia, że co prawda proces podlega kierownictwu generalnej zasady podstawowej, jednakże nie w sensie linearnego konkretnego kierunku. Proces rozwoju, zgodnie z obu modelami, nakierowuje się każdorazowo na dowolny punkt działania danego powszechnego procesu, w którym można dostrzec jego oddziaływanie, gdyż ów proces 
zawsze w pełni podlega owej zasadzie. W przypadku darwinizmu klucz do zrozumienia przeżyć, względnie dążeń jakiegoś indywiduum albo gatunku zawiera się w pełnej podległości dotychczasowemu dopasowaniu. Rozwój, który obserwatorowi jawi się jak postęp ewolucyjny, w rzeczywistości odzwierciedla tylko zasadę mutacji i selekcji. W podobny sposób wyglądają w koncepcji Kanta ślady warunków procesu odnośnie do wszelkich możliwych warunków jego rezultatów. Każdy porządek polityczno-społeczny ludzkości zawsze wskazuje na historię przebiegu porządku społecznego, ludzie zaś, jak przyjmuje Kant, rozumieją aktualnie zachodzący porządek poprzez kategorie postępu lub regresu. A przynajmniej są w stanie to czynić. Pewne podobieństwo koncepcji Kanta i teorii Darwina polega zaś na tym, że dany porządek kierowany jest jakąś niewidzialną ręką. Stawanie się zawsze jest dopełniane przez powrót do tego, co dzieje się aktualnie.

\section{Późna filozofia dziejów Kanta w Krytyce władzy sądzenia, w Ku wieczystemu pokojowi i w Antropologii}

Oczywiste są również różnice pomiędzy koncepcją Kantowską i Darwinowską. Darwin nie jest teleologiem, lecz postępuje zgodnie z empiryczno-przyczynową zasadą wyjaśniania. Kant jest teleologiem, ale też w słabym znaczeniu tego słowa. Inaczej niż Darwin ogranicza swą teorię rozwoju do historii ludzkości. O jakiejkolwiek nieodnoszącej się do człowieka teleologii natury nie ma mowy ani w Idei, ani w żadnym z jego dzieł. Swego teleologicznego rozumienia natury używa gdzie indziej, może w niektórych fragmentach Ugruntowania metafizyki moralności, ale znów chodzi tu tylko o wyjaśnienie zachowania człowieka. Rozważania z zakresu teleologii natury wprowadza po to, by wesprzeć teleologię dziejów (na przykład właśnie w Ugruntowaniu (AA IV 394-396)). Pierwsza część rozwiniętej tam argumentacji (AA IV 395) sprowadza się do zaprezentowania poglądów, że właściwym celem ludzkiej natury jest szczęśliwość. Tezę tę odpiera Kant w następujący sposób. Naturalne predyspozycje każdej żywej istoty są tak ukonstytuowane, że pozostają optymalnie dostosowane do osiągnięcia owego celu. Przyjmijmy zatem, że szczęśliwość stanowi naturalny cel człowieka. Wówczas należałoby stworzyć poszlaki odnoszące się do naturalnych predyspozycji człowieka. W rzeczywistości jednak człowiek w najszerszym zakresie określony jest przez rozum praktyczny. Jeżeli celem człowieka miałoby być dążenie do szczęśliwości, to posiadanie rozumu stanowiłoby $\mathrm{w}$ sferze jego naturalnych predyspozycji element dysfunkcyjny. Silny instynkt byłby przy realizacji tego celu o wiele 
lepszy i o wiele bardziej niezawodny. Druga część (AA IV 396) zawiera afirmatywne stwierdzenie: zgodnie z powyższym, prawdziwe określenie, które ukazuje się w naturalnym ukonstytuowaniu człowieka przez praktyczny rozum, leży w prawdziwym określeniu. Rozstrzygającym punktem jest tu to, że natura obdarzyła nas rozumem praktycznym. Rozum nie służy tylko do użytku teoretycznego, ale, jak powiada Kant, do sprawdzania wpływów działających na wolę. Dobra wola „nie może być wprawdzie jedynym i pełnym dobrem, ale na pewno musi być dobrem najwyższym i warunkiem wszystkiego innego [dobra], nawet wszelkiego pragnienia szczęśliwości” (A IV 396). Istnieją określone zjawiska natury, jak na przykład robactwo albo moskity, których istnienie jest celowe, gdyż mają one pozytywny wpływ na ludzkie zachowanie $e^{6}$. Proces natury, ogólnie rzecz biorąc, przebiega więc zdaniem Kanta antropocentrycznie. U Darwina jest przeciwnie, natura nie ma żadnych quasi-subiektywnych, albo quasi-personalnych własności. Jeśli Darwin przedstawia sobie naturę $\mathrm{w}$ sposób bardziej trzeźwy, jako kontekst walki o przeżycie, to u Kanta jest ona zmodernizowanym wariantem stoicko-chrześcijańskiej opatrzności (pronia, providentia). Gdy chodzi o pojęcie natury, ważny fragment znajdujemy w opublikowanym pięć lat później piśmie $K u$ wieczystemu pokojowi (AA VIII 360-362):

Owo p o rę c z e n i e (gwarancję) daje nam nie kto inny, jak wielka artystka przyroda (natura daedala rerum), z której mechanicznych procesów jasno wynika celowość, każąca ludziom poprzez waśnie, nawet wbrew ich woli, wznieść się do zgody. Dlatego, jako determinująca przyczyna, której prawa oddziaływania nie są nam znane, nazywana jest ona przeznaczeniem, przy rozważaniu jednak celowości w przebiegu [wydarzeń] świata, gdy występuje jako głęboka mądrość wyższej przyczyny, ukierunkowanej na obiektywny, ostateczny cel ludzkiego rodzaju i z góry przesądzającej jego osiągnięcie, Opatrznością nie poznaje my wprawdzie w warsztacie artystycznym przyrody ani nie możemy na jego podstawie nic o niej w n i o s k o w a ć, ale (jak w każdym stosunku formy rzeczy do celu w ogóle) możemy i musimy wyde dukow á ją, by wyrobić sobie pojęcie o jej możliwości na zasadzie analogii z kunsztem czło-

${ }^{6}$ Por. I. Kant, Krytyka władzy sądzenia, przeł. J. Gałecki, PWN, Warszawa, s. 341 i nast.: „Można by np. powiedzieć, że robactwo, które dokucza ludziom w ich ubraniach, włosach lub łóżkach, stanowi, wedle mądrego zrządzenia przyrody, bodziec do czystości, która już sama dla siebie jest ważnym środkiem zachowania zdrowia; albo że moskity i inne kąśliwe owady, które w pustyniach Ameryki tak bardzo dają się we znaki dzikim, są dla tych stawiających pierwsze kroki ludzi bodźcem do działania, by osuszać bagna i karczować gęste, powstrzymujące powiew powietrza, lasy, by dzięki temu, jak i przez uprawę ziemi, uczynić miejsce ich zamieszkania zarazem zdrowszym". 
wieka. Wyobrażenie zgodności [Opatrzności] z celem (moralnym) przypisywanym nam bezpośrednio przez rozum i jej do niego stosunku, to idea, przesadna wprawdzie w odniesieniu t e o r e t y c z n y m, ale w odniesieniu praktycznym (na przykład przy rozpatrywaniu wynikającego z obowiązku pojęcia w i e c z n e g o p o k o j u i wykorzystania w tym celu mechanizmu natury) stanowi ona dogmat i jej realność jest w pełni uzasadniona. - Gdy tak jak w tym wypadku chodzi o teorię (a nie o religię), słowo pr z y rod a lepiej mieści się w granicach ludzkiego rozumu (który, rozpatrując stosunek działań do ich przyczyn, powinien zatrzymać się w granicach możliwego doświadczenia) i jest bardziej skromne, aniżeli pojęcie poznawalnej dla nas Opatrzności, oznaczające zarozumiałe przypinanie sobie ikarowych skrzydeł po to, by zbliżyć się do tajemnicy jej niezgłębionych celów.

We fragmencie tym odnajdujemy $\mathrm{w}$ odnowionej formie liczne wyimki z Idei. Na pierwszy rzut oka bieg natury zdaje się tu mechaniczny, tak naprawdę jednak natura zachowuje się tu celowo. W szczególności jako instrumentem posługuje się niezgodą pomiędzy ludźmi. Nakierowuje się na obiektywny cel ostateczny. Nie możemy w niej odnaleźć ani działających przyczyn, ani praw jej działania, możemy jednak jej celowość stwierdzać. Pojęcie natury pozostaje $\mathrm{w}$ granicach możliwego doświadczenia pojęciowym odpowiednikiem pojęcia opatrzności. W ten sposób nie opiera się ono na metafizycznym dogmatyzmie, lecz tworzy w stosunku do niego alternatywę, bo oddziałujący zamiar postrzegany jest tu jako nieugruntowany.

Pojęcie natury, takie jakie znajdujemy w Idei, z trudnością można uznać za kompatybilne ze współczesnym przyrodoznawstwem. Tym niemniej, jak sądzi Kant, chodzi tu raczej o pojęcie o ograniczonym zakresie, które da się zawrzeć w granicach akceptowalnego użycia rozumu. Jak należy to rozumieć? Zaprezentuję tu trzy możliwe warianty wyjaśnienia (A-C).

A. Antyrelatywistyczny, konstruktywistyczny sposób odczytania. Zgodnie z tą interpretacją coś, co ukazuje mu się jako celowość natury, rozważa Kant jako konstrukt, który daje się użyć jako wiodąca idea w walce o moralno-polityczny postęp. Teza o postępie historycznym, rozumiana po prostu jako idea wiodąca, w ścisłym tego słowa znaczeniu nie odpowiada rzeczywistości. Idea ta raczej mogłaby mieć taką wartość, że w najlepszym wypadku tworzyłaby rzeczywistość, którą rzekomo diagnozowała. Jednakże fakt, że rozprawa Idea powszechnej historii $w$ aspekcie kosmopolitycznym w ogóle została napisana, to znaczy, że pojawił się zamiar wspierania ideału kosmopolitycznego, tylko w niewielkim stopniu mógłby oznaczać, że pismo to powinno 
po prostu sugerować, iż taki bezcelowy rozwój zachodzi. Dla Kanta rozwój celowy istnieje rzeczywiście. Gdyby spojrzeć z naszego obecnego punktu widzenia i rozważyć aktualne tendencje do globalnego rozszerzania demokracji, praw człowieka, wykształcenia, praworządności, zinstytucjonalizowania międzynarodowych stosunków politycznych, oświecenia, postępu nauk i elementarnego dobrobytu, to okazałoby się, że większość współczesnych ludzi przekonana jest o tym, iż pomiędzy rokiem 1784 i współczesnością nie było żadnego znaczącego postępu, który to postęp Kant zakładał w odniesieniu do swoich czasów, jak też dostrzegał go, spoglądając w przeszłość.

B. Odczytanie akcentujące świadomość współczesną. To eleganckie rozwiązanie, za pomocą którego dałoby się wyjaśnić przytoczone powyżej obserwacje, mogłoby polegać na tym, że Kant podstawę historycznego postępu dostrzegał w charakterystycznym historycznym postępie swoich czasów. Już $\mathrm{w}$ antycznych dokumentach historycznych (na przykład mowach Peryklesa, u Tukidydesa, czy we wczesnych tekstach nowożytnych, gdzie tendencja ta wzmocniła się) natrafiamy na szczególny rodzaj świadomości, typowej dla progresywnego rozwoju społeczno-politycznego. Dla tego typu historycznych konstelacji świadomości charakterystyczne jest to, że własne czasy i własną cywilizację uznają za rezultat długiego rozwoju historycznego (albo też za progres w stosunku do oświeconej przeszłości). Fenomen ten w obu wypadkach był bardzo dobrze znany również we wczesnych czasach nowożytnych. Rolę paradygmatu odgrywał tu pierwowzór antyku. Od polityczno-moralnej wartości współczesnej populacji rozpoczynał się zawsze rozwój zarówno wiedzy naukowo-technicznej, jak i geograficznego odkrywania świata. To, że tego typu rozważania w istocie znajdujemy u Kanta, potwierdza na przykład fragment $O$ porzekadle (AA VIII 309 i nast.):

Bo założenie, że jeśli coś nie udało się dotychczas, to nie uda się też nigdy, nie daje jeszcze podstawy, by odżegnywać się od jakichś pragmatycznych lub technicznych celów (jak na przykład podróży powietrznych w balonie aeronautycznym), a w jeszcze mniejszym stopniu daje ono podstawę do odżegnywania się od celu moralnego, zrealizowanie którego, jeśli tylko nie jest ewidentnie niemożliwe, stanowi obowiązek. Mimo tego wszystkiego można przytoczyć liczne dowody na to, że w naszych czasach, w porównaniu z wszystkimi minionymi epokami, rodzaj ludzki jako całość w aspekcie moralnym rzeczywiście znacznie posunął się do przodu, a krótkotrwałe zahamowania niczego jeszcze nie dowodzą i że wrzawa na temat rozrastającego się w niepowstrzymany sposób zepsucia ludzkiego rodzaju wynika akurat stąd, że stojąc na wyższym stopniu 
moralności, ludzkość postrzega dalej i jej sąd na temat tego, czym jesteśmy w porównaniu z tym, czym być powinniśmy, zatem nasze samoobwinianie się, staje się tym ostrzejsze, im więcej stopni moralności [Stufen der Sittlichkeit] przebyliśmy już w trakcie całego, znanego nam biegu historii.

Kant explicite porównuje w powyższym cytacie techniczny i moralny postęp ludzkości. Tekst pozwala też wyraźnie stwierdzić, że w przypadku tego, co obserwowane jest jako rozwój, zdaniem Kanta, nie chodzi po prostu o postęp świadomości współczesnej, lecz o postęp realny. Zgodnie z jego przekonaniem wraz z postępem często pojawia się tu w obrębie dokonującej go społeczności lament nad upadkiem ówczesnej świadomości w nieprawość. U Kanta dostrzegamy również oznaki pozytywnego rozwoju wówczas, gdy $\mathrm{w}$ postępowych moralnie czasach wprowadza się restrykcyjne normy odnoszące się tak do nas samych, jak i do innych. Ma się wrażenie, jak gdyby Kant myślał o rozwoju rozumu w perspektywie rozwoju człowieczeństwa, który do pewnego momentu związany jest ze świadomością faktycznego żyjącego człowieka, ale nie pozwala się zredukować tylko do takiej perspektywy.

\section{Odczytanie w sensie kosmopolitycznej stoickiej teologii natury i ro-} zumu. W późnej Kantowskiej Antropologii w aspekcie pragmatycznym znajduje się fragment, który potwierdza podstawową tezę z Idei, łącząc ją jednak explicite $\mathrm{z}$ dychotomią zasady czysto regulatywnej, a nie konstytutywnej:

Charakter gatunku, na ile jest on znany na podstawie doświadczenia wszystkich czasów i wszystkich narodów, to to, że wzięty kolektywnie (jako całość rodzaju ludzkiego) stanowi wielość osób egzystujących po sobie i obok siebie, które nie dają sobie rady bez pokojowego współżycia, a przy tym nie mogą uniknąć nieustannych konfliktów. Co za tym idzie, za sprawą wzajemnego przymusu do podporządkowania się prawom pochodzącym od nich samych czują się z natury przeznaczeni do zawiązania nieustannie zagrożonego poróżnieniem, ale powszechnie postępującego światowego społeczeństwa obywatelskiego (cosmopolitus). Samo w sobie jest ono ideą, nie zasadą konstytutywną (zasadą oczekiwania trwałego pokoju bez względu na najżywotniejsze działania i przeciwdziałania ludzi), lecz zasadą jedynie regulatywną. Głosi ona, że należy do niego jako do przeznaczenia rodzaju ludzkiego pilnie się zbliżać, a przypuszczenie naturalnego ukierunkowania $\mathrm{w}$ tę stronę nie jest pozbawione solidnych podstaw ${ }^{7}$.

${ }^{7}$ I. Kant, Antropologia w ujęciu pragmatycznym, przeł. E. Drzazgowska i P. Sosnowska, Warszawa 2005, s. 308 i nast. 
Fragment ten podejmuje myśl gatunkowego rozwoju człowieka, powołując się na społeczny antagonizm ludzkich indywiduów. Obok bezpośredniego rozróżnienia pomiędzy zasadami regulatywnymi i konstytutywnymi (których w Idei jednak brak), dopełnia on tutaj myśl stoików, głoszącą, że zgodnie z naszą naturą lub rozumem czujemy się zdeterminowani do tego, by przejść do „powszechnie postępującego światowego społeczeństwa obywatelskiego (cosmopolitus)" ". Tym, co skłania nas do takiej myśli jest sam rozum. Tutaj zaś Kant zbliża się do ujęcia kosmopolityzmu charakterystycznego dla rzymskiej Stoa. Człowiek sam kształtuje sobie historię. Perfekcyjny zewnętrzny ustrój państwa przedstawiany jest tu zgodnie z Idea, jako cel historii, a najwyższe polityczne dobro, czyli trwały pokój pomiędzy, ukonstytuowanymi jako republiki, państwami tworzącymi związek narodu, zgodnie z Ku wieczystemu pokojowi, czyli jako taki, który zostanie w przyszłości osiągnięty.

Rozstrzygającym punktem wyjścia dla Kantowskiej odnowy sposobu myślenia o celowości oraz teleologii, i to zarówno w naturze, jak i w historii, jest nauka postulatów z Krytyki praktycznego rozumu. Podobnie jak takie rozszerzenie naszego horyzontu poznawczego ważne jest ponad doświadczeniem, bo pisze się tu o Bogu, wolności i nieśmiertelności jako warunkach możliwej moralności, również w przypadku teleologii historii chodzi o konieczne warunki powodzenia normatywności politycznej. Dlatego Kant jest zdania, że teleologia historii ma charakter idei regulatywnej. Zdaniem Kanta niepojęte jest, by pojmować historię ludzkości w taki sposób, jak gdyby była ona zorientowana na moralność i postęp. W Idei brak tego odniesienia do praktycznego rozumu, które stanie się centralne w $\$ 83$ Krytyki władzy sądzenia. Czytamy tam:

Formalnym warunkiem pod jakim przyroda ten swój zamierzony cel może osiągnąć, jest taki ustrój we wzajemnych stosunkach między ludźmi, w którym szkodom wynikającym ze wzajemnie się zwalczającej wolności przeciwstawiona zostaje praworządna siła w [ramach] pewnej całości, noszącej nazwę społeczności obywatelskiej, gdyż tylko w niej może dojść do najpomyślniejszego rozwoju naturalnych dyspozycji. Dla niej wszakże, o ile ludzie byliby dość rozsądni, by ją znaleźć, i dość mądrzy, by dobrowolnie poddać się jej przymusowi, potrzebna byłaby jeszcze całość kosmopolityczna, tj. system wszystkich państw, którym grozi niebezpieczeństwo wzajemnego negatywnego oddziaływania na siebie'.

\footnotetext{
${ }^{8}$ Tamże.

${ }^{9}$ I. Kant, Krytyka władzy sądzenia, s. 426.
} 
Kantowska filozofia historii posiada jednakże głęboko paradoksalną strukturę. Z jednej strony napotykamy tu koncepcję, zgodnie z którą możemy być przekonani o możliwości zrealizowania polityczno-prawnych norm, mimo przeciwnych im warunków. Bo gdyby aktor nie mógł żywić nadziei na to, że działając zgodnie z normami standardu okaże się skuteczny i że w ten sposób uczyni świat polityczno-społeczny lepszym, to motywy postępowania byłyby niewystarczające, a dotyczące go nakazy zawisłyby w próżni. Wiąże się z tym również zaprezentowana powyżej sytuacja norm moralnych, którą musi sobie uświadomić także aktor Kant, a mianowicie, że imperatyw kategoryczny bez nadziei na pojednanie cnotliwego postępowania i szczęśliwości jako jego skutku potrzebowałby wsparcia, które nie wynikałoby z motywacji przez nadzieję spełniania. Istnienie Boga, ludzkiej wolności i nieśmiertelności duszy są zatem postulatami, które należy zaakceptować, ażeby osiągnąć pogodzenie normatywnych żądań z realistycznymi warunkami skutków działania. $\mathrm{Z}$ drugiej strony Kantowska filozofia dziejów niweczy jednak warunki efektów normatywności, bo jeśli się reprezentuje optymistyczną filozofię dziejów, która mocą Boga lub natury wszystkim zarządza dla dobra człowieka, to w przyszłości, niezależnie od tego co czyni indywidualny aktor, nadejdzie to, co najlepsze. Zaniechanie nie byłoby wówczas mniej celowe, aniżeli działanie, gdyby przyjąć optymistyczną filozofię dziejów. Pojawia się tu konieczna podstawowa zasada, zgodnie z którą historia również wówczas nie jest bezsensowna, ani pozbawiona rekompensaty. Jeśli jednak taka rekompensata nie istnieje, wówczas każde wydarzenie w świecie, również własne działanie, też miałoby najlepszy z możliwych sensów. O ile jednak przyjmiemy perspektywę natury lub Boga, historia okaże się procesem nakierowanym na cel, w ramach którego ludzcy aktorzy podlegają nakazowi, którego spełnienie równie nie wpływa na osiągnięcie celu, jak i niespełnienie go na jego utratę. Nie ma zatem żadnego otwartego horyzontu, w którym możliwe byłoby równocześnie spełnianie celu oraz zarzucanie go. Nie ma nawet żadnego otwartego horyzontu, w którym równocześnie możliwe jest spełnianie i zaniechanie celu, a obie możliwości byłyby postrzegane jako relatywnie prawdopodobne. Dobry wynik występuje tu raczej niezależnie od tego, kto i co przedsięweźmie dla swojego dobra. Normatywność jest więc tylko wówczas sensowna, gdy punkt wyjścia praktycznej sytuacji jest otwarty i gdy aktor poprzez wykorzystanie owej otwartej sytuacji zwróci się ku dobru. 


\section{Abstract \\ Kant's Philosophy of History and its Underlying Difficulties}

The article analyses four main difficulties in the attempts of reconciling the Kant's philosophy of history with his philosophical standpoint as a whole. They are: (I) the problem of dogmatism, (II) the problem of heteronomy, (III) the problem of cynicism, and (IV) the problem of fatalism. Kant himself refutes these objections in a quite satisfactory way. 